\title{
Differences in the Effect of Small Sided Game and Drill Training Methods on Passing Accuracy and V02Max in Football Games in High School Students
}

\author{
Muhammad Asrul ${ }^{1}$, Tarsyad Nugraha ${ }^{2}$, Indra Kasih ${ }^{3}$ \\ ${ }^{1}$ Postgraduate Sports Education, Universitas Negeri Medan, Indonesia \\ ${ }^{2,3}$ Faculty of Sport Science, Universitas Negeri Medan, Indonesia \\ muhammadasrul490@gmail.com,cats.nugraha@gmail.com,kasihindra833@gmail.com
}

\begin{abstract}
This study aims to determine the difference in the effect of small sided games and drill on passing accuracy and VO2Max in soccer games. This research is using experimental method. The sample in this study is 26 people, then divided into two groups using matching by fairing techniques. The results of this study, namely the first hypothesis obtained t-hit of 6.96 and t-table 1.78, then (6.96> 1.78) Ha is accepted and $\mathrm{Ho}$ is rejected. The second hypothesis is obtained t-hit of 4.98 and t-table 1.78, then (4.98> 1.78) $\mathrm{Ha}$ is accepted and Ho is rejected. The third hypothesis is obtained t-hit of 13.01 and t-table 1.78, then (13.01>1.78) Ha is accepted and Ho is rejected. The fourth hypothesis is obtained $t$-hit of 5.79 and t-table 1.78, then (5.79> 1.78) Ha is accepted and Ho is rejected. The fifth hypothesis is obtained t-count 3.063 and $t$ table 1.71 (3.063> 1.71) and (0.005 <0.05) then Ha is accepted and $\mathrm{Ho}$ is rejected. The sixth hypothesis is obtained t-count 3,971 and t-table 1,71 (3,063> 1,71) and $(0,001<0,05)$ then $\mathrm{Ha}$ is accepted and Ho is rejected. The conclusion of this study is, There is a significant effect of the small sided games training method on improving passing accuracy. There is a significant effect of the drill training method on increasing passing accuracy. There is a significant effect of the small sided games training method on increasing VO2max. There is a significant effect of the drill training method on increasing VO2max. There is a significant difference in the effect of the small sided games training method with the drill on improving soccer passing accuracy. There is a significant difference in the effect of the small sided games training method and the drill training method on increasing VO2Max.
\end{abstract}

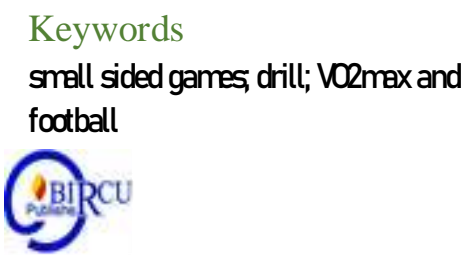

\section{Introduction}

The purpose of national education is so noble, because with the achievement of these goals, all social problems can be overcome including students as the next generation of the nation. Physical education, sports and health is one of the entry points, because it develops; physical fitness, movement skills, critical thinking, social, reasoning, emotional stability, moral actions, aspects of a healthy lifestyle and the introduction of a clean environment through physical activities can be formed by young people who have quality human resources (Pandaleke et al, 2019). Sports and Health Physical Education is an education that can be carried out by doing physical sports activities, which aim to maintain and improve physical fitness, in which there are various aspects which include: speed, agility, strength and endurance (Prasetyo, 2020). 
Football is a team game, which consists of eleven players with each team consisting of goalkeepers, defenders, midfielders and forwards. Football is a sport that is quite popular and is played in groups. According to Nusri (2019: 31) football is a sport which is classified as a team sport, players are required to work together. The game of football aims to score goals into the opponent's goal and try to prevent the opponent from scoring into his own goal. In game development football can be played outside the field and indoors closed (Sucipto, 2000: 7). Football is a sport that has developed rapidly among the people, all people can enjoy playing football starting from children, young people and even parents (Aminudin et al, 2020).

The development of football in Indonesia can be said to be quite rapid, it can be seen from the many professional clubs that compete at the national level. At the same time, in Indonesia there are also a lot of football coaching, starting from soccer schools and coaching at the school level, namely in the extracurricular field. Because of the large number of football coaching, of course the competition will increase. However, this is the positive side of the progress of football in Indonesia in general.

In coaching the sport of football, of course, the most priority is mastery of the basic techniques of football. Mastery of basic football techniques is very important for every child who is learning as the main capital in the game. One of the basic techniques that must be mastered by children who are learning football is the passing technique. Passing according to Mielke (2007: 19) is to transfer the momentum of the ball from one player to another. Then Koger (2007: 19) said that the main purpose of passing is to flow the ball to create opportunities to score goals. It can be concluded that passing is a technique of passing the ball to a teammate to try to score a goal. Apart from mastery of soccer passing techniques, children who are learning football must also have a good VO2Max level, because the better a person's VO2Max, the easier it will be for him to follow football technical training.

To improve your soccer passing skills and increase your VO2Max, there are many good training methods to apply. Such as small sided game training methods, drill training methods, and many other training methods. In this study, the training methods that will be applied are the small sided games training method and the drill training method. The choice of this training method is because it has the same characteristics in its implementation but its implementation is different. When viewed from previous research, these two training methods have a significant effect on improving passing accuracy and VO2Max. Therefore, the researcher wants to test these two training methods, which training method has the greatest effect on increasing the accuracy of passing and VO2Max in soccer games.

The purpose of this study was to obtain empirical facts about: (1) the effect of the small sided game training method on soccer passing accuracy, (2) the effect of drill training on soccer passing accuracy, (3) the effect of the small sided game training method on vo2max, (4) ) the effect of the drill training method on vo2max, (5) differences in the level of passing accuracy in soccer games between students trained using the small sided game training method and the drill training method, (6) the difference in VO2Max between students trained using the small sided training method games and drill practice methods. 


\section{Research Methods}

To obtain research data, researchers used experimental methods. The experimental method according to Sugiyono (2009: 72) can be interpreted as a research method used to find the effect of certain treatments on others under controlled conditions. This research was conducted at SMA Negeri 1 Tambangan, the population of which was all students who took part in football extracurricular activities totaling 26 people, while the sample in this study amounted to 26 people with a total sampling technique, namely including the entire population as a sample. Then the entire sample was divided into two groups using the matching by fairing technique from the initial passing test.

In research, a research instrument is needed as a tool in data collection. The instrument in this study used a short bait test to receive the ball according to Nusri (2019: 8) while to measure VO2max using the bleep test. Collecting data in this study using observation, documentation, and tests. This research was conducted from October 2019 to November 2019. Then after the initial test and final test data were obtained, then the data was processed using the t-test.

\section{Results and Discussion}

\subsection{Results}

Pre-test data for group passing accuracy using small sides games training method using liliefors. Based on the normality test of the pre-test data for the accuracy of passing in the small sides games training method group, it was obtained L-Hit (0.035) and L-Table $(0.234)$ then $(0.035<0.234)$. It can be concluded that the pre-test data for the accuracy of passing in the small sides games training method group has a "Normal" distribution.

Based on the normality test of the pre-test data for the accuracy of passing in the drill training method group, the L-Hit (0.115) and L-Table (0.234) were obtained $(0.115$ $<0.234)$. It can be concluded that the pre-test data of passing accuracy in the drill training method group has a "Normal" distribution.

Based on the normality test of VO2Max pre-test data in the small sides games training method group, it was obtained L-Hit (0.048) and L-Table (0.234) then (0.048 $<0.234)$. It can be concluded that the VO2Max pre-test data in the small sides games training method group has a "Normal" distribution.

Based on the normality test of VO2Max pre-test data in the drill training method group, it was obtained L-Hit $(0.092)$ and L-Table $(0.234)$ then $(0.092<0.234)$. It can be concluded that the VO2Max pre-test data in the drill training method group has a "Normal" distribution.

Homogeneity test was performed using the chi-square test, obtained X-count data pre-test and post-test that is 20.34 and X-table $(0.05)$ of 38.88 . So $(20.34<38.88)$ the pretest and post-test data for the accuracy of passing the small sides games exercise group is "Homogeneous".

For the drill practice group, it was obtained X-count data for pre-test and post-test, namely 23.09 and X-table $(0.05)$ of 38.88 . So $(23.09$ <38.88) the pre-test and post-test data of the passing accuracy of the drill training group is "Homogeneous".

The homogeneity test of the small sided game group for VO2max obtained X-count data of pre-test and post-test, namely 18.16 and X-Table $(0.05)$ of 38.88. So $(18.16<38.88)$ the VO2Max pre-test and post-test data for the small sides games exercise group was "Homogeneous". 
The homogeneity test of the drill group for VO2max obtained X-count data for pretest and post-test, namely 18.06 and X-Table $(0.05)$ of 38.88 . Then $(18.06<38,88)$ VO2Max pre-test and post-test data of the drill practice group were "Homogeneous".

The first hypothesis test obtained t-hit of 6.96 and t-table 1.78, then (6.96>1.78) Ha is accepted and Ho is rejected. It can be concluded from the data that there is a significant effect of the small sides games training method on improving the accuracy of soccer passing.

The second hypothesis test obtained t-hit of 4.98 and t-table 1.78 , then (4.98>1.78) Ha was accepted and Ho was rejected. It can be concluded from the data that there is a significant effect of the drill training method on increasing the accuracy of soccer passing.

The third hypothesis test obtained t-hit of 13.01 and t-table 1.78, so (13.01> 1.78) Ha is accepted and Ho is rejected. It can be concluded that the hypothesis is proven by the data that there is a significant effect of the small sides games training method on the increase in VO2max.

The fourth hypothesis test obtained t-hit of 5.79 and t-table 1.78 , then $(5.79>1.78)$ Ha was accepted and Ho was rejected. It can be concluded that the hypothesis is proven by the data that "there is a significant effect of the drill training method on increasing VO2max.

The fifth hypothesis test obtained t-count 3.063 and t-table $1.71(3.063>1.71)$ and $(0.005<0.05)$ then $\mathrm{Ha}$ is accepted and Ho is rejected. It can be concluded that there is a significant difference between the small sides games training method and the drill training method on improving the accuracy of soccer passing.

The sixth hypothesis test obtained t-count 3,971 and t-table 1,71 $(3,063>1,71)$ and $(0,001<0,05)$ then Ha is accepted and Ho is rejected. It can be concluded that there is a significant difference between the small sides games training method and the drill training method on the increase in VO2max.

\subsection{Discussion}

\section{a. The Effect of Small Sided Games Training Methods on Increasing the Accuracy of Football Passing}

The results showed that there was a significant effect of the small side games training method on improving the accuracy of soccer passing. With the small side games training method the players get more contact with the ball, learn faster and have to make more decisions during the game (more concentration is required because the ball is never far away). As seen in the field when doing the exercises, students were doing more passing. Because there are fewer players in the process, it makes it easier for students to pass correctly to teammates. Thus there is an increase in student passing accuracy in soccer games.

\section{b. Effect of Drill Training Methods on Improving Football Passing Accuracy}

The results prove that there is a significant effect of the drill training method on improving the accuracy of soccer passing. The drill training method is an exercise that emphasizes the technical components. The drill training method is a teaching method in which students are immediately invited to go to the experimental/skill practice area, such as to see how to do something, how to do it, what to do, what are the benefits, and so on. The drill method is intended to gain dexterity or skills, especially in passing skills, because only by practically doing a knowledge can be perfected. By using the drill training method in this passing movement, the movement repeats itself repeatedly so that it allows students to make the same movements continuously which can then increase the accuracy of passing when playing football. 


\section{c. The Effect of the Small Sided Games Training Method Against V02max}

The results showed that there was a significant effect of the Small Side Games training method on the increase in VO2Max. This is because according to the researcher there has been an increase in movement activity during training which makes students continue to move until there is a signal for a break from the coach. It is this activity of moving or running that is continuously carried out which allows an increase in the VO2max of the students during training. This form of training can increase the VO2max of students in soccer games. Therefore, research has shown that small sided games can increase VO2Max.

\section{d. The Effect of the Drill Practice Method on VO max}

The results showed that there was a significant effect of the drill training method on increasing VO2Max. The drill training method has special value in developing the lung capacity level or VO2MAx. Physical movement is one of the best ways to increase VO2MAx. To increase VO2MAx by practice aimed at specific repetitions. Based on the description above, it can be concluded that drill passing exercises have the characteristics of moving continuously and consuming a lot of energy. So that by moving continuously can increase the VO2MAx of students in playing football. This study proves the data that the drill training method can increase the VO2Max of students in playing football.

\section{e. Differences in the Effect of Small Sided Games Training Methods and Drill Training Methods on Improving Football Passing Accuracy}

The results of the study prove that there is a significant difference in the effect of the small side games training method with the drill training method on increasing the accuracy of soccer passing. Small-sided games training method is a football game with fewer players than usual on the field and the form of the field is smaller than usual. In this practice players are required to be more active and must keep moving. The main element in the small side game practice is cooperation between friends so that passing techniques are highly demanded. The characteristic of this small side game training method is the form of the game that almost matches the actual game. What distinguishes is that the number of players is small from the actual number, namely 11 people, and the size of the field is reduced from the actual size.

While the drill training method has the characteristics of repeating the same movements continuously so that movement skills are created. Each corner is filled in by students for passing. The simpler the Drill practice method is to form a parallelogram pattern. Each student must pass right to the friend who is at another corner and then move from the original place. Because the focus of passing must be right on a friend who is at another corner, accuracy in passing is also highly demanded by this training method. This study proves the data that the small sided games training method has a greater effect than the drill training method on increasing the accuracy of soccer passing. According to researchers, one of the factors in the occurrence of these differences is the characteristics of the small sided game that is implemented into a game. So students feel more happy and enthusiastic when doing movements. 


\section{f. Differences in the Effect of Small Sided Games Training Methods and Drill Training Methods on Increasing VO2Max}

The results showed that there was a significant difference in the effect of the small side games training method and the drill training method on the increase in VO2Max. To achieve the training target, students must have a good physical fitness condition so that it is easier to follow every process of implementing the exercise. People with good fitness levels have higher VO2max values and can do more vigorous activities than those with lower VO2max levels. Vo2max is the highest value at which a person can consume oxygen during exercise, and is a reflection of the cardiorespiratory and haematological elements of oxygen delivery and muscle oxidative mechanisms.

It can be seen from the research, students who are trained using the small sided games exercise method are more enthusiastic and are more likely to work hard during practice when compared to students trained using the drill method. It seems that the students are more agile at the time of practice because the small sided games practice method is that students are happier because they play games. It can also be seen in the drill practice method that students make continuous movements, but sometimes they forget the direction of the next movement so that they often misunderstand among their fellow group members. Thus, the results of the VO2max test between students who were trained with the small sided game training method with the drill training method were significantly different.

\section{Conclusion}

Based on the results of the study, it can be concluded that this study is: (1) there is a significant effect of the small sided games training method on improving the accuracy of soccer passing. (2) there is a significant effect of the drill training method on improving the accuracy of soccer passing, (3) there is a significant effect of the small sided games training method on the increase in VO2Max, (4) there is a significant effect of the drill training method on increasing VO2Max, (5) there is a significant difference in the effect of the small sided games training method with the drill training method on increasing the accuracy of soccer passing, (6) there is a significant difference in the effect of the small sided games training method with the drill training method on the increase in VO2Ma.

The suggestions that can be submitted by researchers are: (1) Small sided games training methods and drill training methods can be applied to improve the passing accuracy and VO2Max of football players. (2) The small sided games training method is significantly better than the drill training method to improve passing accuracy and increase VO2max, therefore it is advisable for football coaches to use the small sided games method, but the drill training method is also good so these two training methods are it would be better if applied alternately so that boredom does not occur during training. (3) Sports coaches or teachers in schools are advised to do the small sided game training method and the drill training method as an effort to improve the ability of students or athletes, because this can be done despite the availability of simple tools. 


\section{References}

Aminudin, et al. (2020). Contribution Leg Muscle Strength, Dynamic Balance and Hip Joint Flexibility to the Accuracy of Football Shooting. Budapest International Research and Critics in Linguistics and Education (BirLE) Journal, 912-918.

Bompa, O. Tudor (1983). Theory And Methodology Of Training. Dubuguque, Iowa Kendal / Hunt Publishing Company.

Danny Mielke. (2007). Basics of Football. Bandung: Expert Raya.

Harsono. (1988). Psychological Aspects in Coaching. Jakarta: CV. Tambak Kusuma Jakarta.

Joseph A. Luxbacher. (2011). Football. Second Edition. Jakarta: PT Raja Grafindo Persada.

Nusri Ardi (2019). Effective Football Theory And Practice. Publisher: Cipta Prima Nusantara

Nusri Ardi. (2018). Football Skills Test Handbook For SSB. Publisher: Cipta Prima Nusantara

Pandaleke, et al. (2019). The Effect of Balance, Arm Muscle Strength, and Creativity towards Discus skills on Faculty of Students of Manado State University Science. Britain International of Linguistics, Arts andEducation(BIoLAE)Journal, 160-174.

Prasetyo, G., et al. (2020). The Impact of Physical Activity to Physical Fitness and Nutrional Status of Grade X Surabaya Vocational High School. Britain International of Linguistics, Arts andEducation(BIoLAE) Journal, 590-597.

Snow Sam. (2011). Small Sided Games Manual. Human Kinetics Inc.

Sugiyono. (2010). Educational Research Methods with Qualitative Approaches, Qualitative, and R \& D Bandung: CV. Alfabeta. 